\title{
Analysis of the pharmaceutical assistance cycle in Romelândia, Santa Catarina, Brazil
}

\author{
Patrícia Prevedello", Maria Assunta Busato2,"*
}

${ }^{1}$ Health Secretary, Romelândia, SC, Brazil, ${ }^{2}$ Health Sciences, Chapecó Regional Community University, Chapecó, SC, Brazil

\begin{abstract}
The Pharmaceutical Assistance Cycle (PA) is the basis for healthcare services through which pharmaceutical assistance and expertise can be implemented in a functional and structured way to meet public health demands, adhere to the Brazilian Ministry of Health vision, and strike a balance in the contemporary struggle for health equity. The aim of this research is to analyze the effectiveness of the PA cycle in the city of Romelândia (SC), through a study conducted at a Primary Healthcare Unit in the municipality. For the study, 120 patients (service users) and seven healthcare professionals were interviewed. The majority of patients confirmed that they were given advice and instruction on dosage during the dispensing process, as well as advice on the recommended use of medicines and course duration. A small number of service users, $4.1 \%$, said that they received instructions on adverse drug interactions; $36.6 \%$ commented on a lack of access to medicines available in the municipal pharmacy, and $71.4 \%$ of the health professionals interviewed, identified non-availability of medicines in the pharmacy as the most pressing and telling problem facing the service. There is also no local Pharmacy and Therapeutics Committee, and the only selection criteria is the Ministry of Health essential medicines list. Our study has therefore identified several weaknesses facing the city healthcare service, namely: the shortage of medicines; a lack of resolute professional communication between pharmacist and service user; a lack of patient counseling during the dispensing process, and a lack of communication regarding patient follow-up treatment and wellbeing.
\end{abstract}

Uniterms: Pharmaceutical Assistance. Medicines/appropriate use. Patients/use of medicines. Medicines/ use instructions.

O ciclo da Assistência Farmacêutica (AF) é o norte para a implementação das ações da AF nos serviços de saúde de maneira estruturada e funcional como preconiza o Ministério da Saúde. O objetivo deste estudo foi diagnosticar as ações do ciclo da AF em Romelândia (SC). O estudo foi realizado na Unidade Básica de Saúde do município onde foram entrevistados 120 usuários e sete profissionais de saúde envolvidos diretamente nas ações de AF. Dos 120 usuários entrevistados, a maioria recebe orientações no momento da dispensação sobre a posologia, modo de usar e duração do tratamento. Poucos $(4,1 \%)$ recebem informações sobre interações e reações adversas 36,6\% não encontram o medicamento na farmácia municipal quando necessitam e para $71,4 \%$ dos profissionais, a falta do medicamento na farmácia é o principal problema da Secretaria de Saúde (SS), pois não atende a quantidade programada. O município não tem Comissão de Farmácia e Terapêutica e o critério para a seleção dos medicamentos na SS é a lista da farmácia básica e a demanda. O estudo indica como fragilidade, a falta constante do medicamento e de orientação farmacêutica no momento da dispensação bem como o acompanhamento dos usuários.

Unitermos: Assistência farmacêutica. Medicamentos/uso apropriado. Pacientes/uso de medicamentos. Medicamentos/instruções de uso.

\footnotetext{
*Correspondence: M.A. Busato. Universidade Comunitária da Região de Chapecó. Rua Attílio Fontana, 591E, CEP: 89809-000 - Chapecó, SC, Brazil. Email: assunta@unochapeco.edu.br
} 


\section{INTRODUCTION}

The aim of our study was to assess the current status of Pharmaceutical Assistance (PA) in Romelândia, a town located in the western region of Santa Catarina State. Attention is given to the PA cycle, the services and delivery, as well the difficulties the healthcare team faces with implementing PA and dispensing medicines. We also assess the opinion of health service users on the role of the pharmacist in giving medication advice.

Article 6 of Brazilian National Health Law 8080/90 stresses the key role of therapeutic assistance in the Brazilian Unified Health System (SUS). Law 8080/90 gives particular importance to pharmacotherapeutic procedures and activities directly involving or linked to pharmaceutical services (Brazil, 1990). According to the Ministry of Health, "Pharmaceutical Assistance concerns the drug-related activities which support healthcare services demanded by a community. This involves the supply of medicines in each and every constituent step: storage, quality control, safety, and therapeutic efficacy of drugs; monitoring and assessment of usage; provision and dissemination of drug information; and the continuing education of healthcare professionals, patients, and the community to ensure the rational use of medicines" (Brazil, 1998).

The PA cycle is therefore a central public healthcare mechanism facilitating the equitable and proficient implementation of a pharmaceutical service by ensuring and monitoring the selection, scheduling, purchasing, storage, distribution, and dispensing of medicines in a timely and requisite manner (Brazil, 2001).

The selection phase is the most crucial step in the PA cycle, for it is here that the list of essential selected medicines is created (Marin et al., 2003). In theory, the selection phase is the most effective, and indeed the safest way to select medicines crucial for meeting the needs of a given population (Brazil, 2001). Selection must be based on epidemiological, technical, and economic data established by the Pharmacy and Therapeutics Committee (P\&T Committee) whose aim is to select safe, adequate, and cost-effective medicines in order to justify usage, standardize therapeutic conduct, and guide the purchasing process (Brazil, 2006). Proper selection cannot therefore be undertaken without a P\&T Committee. Indeed, without establishing ethical evidence-based Committee consensus, the availability of appropriate pre-selected medicines which meet public needs cannot be guaranteed, and promotion of the rational and measured use of drugs (RUD) will remain divorced from the selection stage (Marin et al., 2003). Likewise, a P\&T Committee can guide volume demand projections according to available resources, so as to meet community demand, prioritize the purchasing of medication, and avoid unnecessary purchase surplus, loss, or shortage (Brazil, 2001). The role of a pharmacist is crucial to this purchasing process, ensuring safe storage and a balanced distribution and availability of medicines.

In Brazil, healthcare professionals hold a fragmented view of services related to medicines, for although purchasing, storage and dispensing are controlled, the pharmacist is excluded from other important steps of the PA cycle (Marin et al., 2003). In 2004, the National Policy of Pharmaceutical Assistance was approved, establishing that Pharmaceutical care, as a pharmacy practice model, is undertaken by the pharmacist in strict accordance with the patient, aiming at improving quality of life through the monitoring of patient pharmacotherapy (Brazil, 2004). Such a policy can help improve PA services and the overall health governance of a population by highlighting the important role played by the pharmacist in public health provision and in so doing improve service delivery.

\section{MATERIAL AND METHODS}

Research was conducted in the city of Romelândia, located in the western region of Santa Catarina State, Brazil, $721 \mathrm{Km}$ from the state capital, Florianopolis. The town/municipality covers a total area of $224 \mathrm{Km}^{2}$, which is subdivided into 35 districts or communities (Romelândia, 2009). The Brazilian Institute of Geography and Statistics (IBGE) census in 2010 records a population of 5,551 inhabitants, of which 3,543 live in rural and 2,008 in urban areas.

One central and four rural healthcare units provide weekly medical, dental, and nursing services for the urban and rural population. Two of these units, however, are not currently in operation.

Romelândia also has two Family Health Teams (FHTs) consisting of a doctor, a nurse, a dentist, a dental assistant, a nursing technician, and ten community healthcare workers. The healthcare team also has two pharmacists (contracted for 20 hours per week in the laboratory); a laboratory assistant; a nursing assistant; two administrative clerks; and one local health surveillance technician.

The seven professionals who are engaged in the PA cycle (a doctor, two nurses, a pharmacist, an administrative clerk, and two nursing technicians) were interviewed for this study. Also, 120 randomly selected service users ( $\mathrm{IC}=95 \%$ ) participated in the study; they included men and women aged between 18 and 70 years, of differing education and professional backgrounds, and from both 
urban and rural areas. These participants corresponded to $5 \%$ of pharmacy service users at the time of the study. Interviewee selection was on a first come first served basis, where the first five users visiting the pharmacy each weekday morning, between September and October 2010, were approached.

Semi-structured interviews were used for data collection, with specific questions related to PA cycle stages (selection, scheduling, purchasing, storage, distribution, dispensing, and monitoring of medicines). Based on World Health Organization (WHO) recommendations and the Ministry of Health (Brasília), two questionnaires were adapted from Costa (2005) - one for healthcare professionals and the other for service users. These questionnaires were administered during September and October 2010 by a researcher and pharmacist in Romelândia. The researcher did not participate in the study, and only one pharmacist answered the questionnaire. During data collection, only one doctor was on site, even though the municipality declares two FHTs.

Our study was approved by Chapecó Regional Community University (Unochapecó) Ethics Committee, protocol No. 121/2010.

\section{RESULTS AND DISCUSSION}

The majority of service users were from rural areas (77.5\%): $75.8 \%$ were farmers, who collected medication on a monthly basis (56.6\%). This can be explained by the fact that people living in rural areas usually visit the city once a month to fulfill other obligations, such as banking or shopping: the logistics of the situation is that patients attend the Health Unit, not so much when they need to, but when they can. At time of interview, $66.6 \%$ of service users had up to an elementary education level.

Patient understanding of the instructions received when collecting medication indicated a lack of guidance from the pharmacist. This could be one of the reasons for service users failing to continue a prescribed course of treatment. According to Silva et al. (2000), a lack of information on the adverse effects of prescribed medicines may be related to the low value given to such information by prescribers in university hospitals and by those using the medication. Indeed, the prescriber very often avoids communicating adverse effects to service users, fearing that such information may affect patient confidence in treatment or that the patient might feel, by self-suggestion, these adverse effects (see Table I). Our study did highlight this: $35 \%$ of patients reported having once abandoned a drug treatment of which $40.4 \%$ gave "the possibility of adverse reactions" as the main reason for this.
TABLE I - Patient opinion concerning advice given when collecting medication

\begin{tabular}{lc}
\hline Viewpoint & $\%$ \\
\hline Usage & 92.5 \\
Dosage & 92.5 \\
Course of treatment & 90.0 \\
Drug interaction & 4.1 \\
Drug-food/beverage indication & 11.6 \\
Non-availability of medicines & 37.5 \\
\hline
\end{tabular}

The lack of a full-time dispensing pharmacist may indeed result in a failure to effectively communicate with service users and have a direct impact on patient awareness and public health education. The World Health Organization, for example, states that the pharmacist is the professional best suited to take actions which improve access and promote RUD - the pharmacist has a crucial role to play in delivering support services and developing the PA cycle (WHO, 1988). Cultivation of patient awareness with regard to a course of treatment or a particular medication may lead to an increase in service user confidence thus minimizing the probability of the patient abandoning therapy. To achieve the desired goals, the patient must receive information on possible adverse reactions, on potential drug and food interactions, on the importance of following the prescribed course of treatment, and on the correct therapeutic regimen, including intervals when and if required (Santos, Nitrini, 2004). Pharmacists are therefore the most aptly attuned and aware professionals to fulfil this responsibility; their presence in both public and private sectors is crucial in accomplishing RUD (Arrais et al., 2007).

It is the pharmacist who has an expert knowledge of medication and who consequently must advise, monitor, and in some cases motivate patients to adhere to treatment. Public and professional awareness, and indeed affirmation of such a role, is however still new to the Brazilian public healthcare scenario. This is partly due to difficulties faced by pharmacists in applying their formal knowledge within patient service settings. Consequently the parameters for assessing the impact of their work on service delivery and the improvement of population health are yet to be fully elaborated and appreciated. There is therefore a current urgency for pharmacists to truly understand and assert their professional identity and for the public health services to facilitate full pharmacist participation, together redefining their relationship with medicine and giving it a new professional and social dimension (Araujo et al., 2008). 
The non-availability of medicines flagged by both service users (Table I) and staff (Table II) is an ongoing predicament not just in Romelândia: access to medicines is a seemingly perennial problem, if not a constant equity challenge for the Brazilian healthcare system as a whole. In 2003, the Brazilian Institute of Consumer Defense (IBDC, 2003) sought to assess the Federal Government's provision and free distribution of essential medicines. In the 50 healthcare units of 11 sampled cities, IBDC observed a serious shortage where only $55.4 \%$ of the surveyed medicines were available. In a similar study on the availability of essential medicines in municipalities with a human development index of $<0.699$, Guerra Jr. et al. (2004) identified a low availability pattern in the public and philanthropic sectors. This said, it is low-income earners in the Brazilian population who are the most vulnerable as they are completely dependent on the free availability of medication. It has also been estimated that more than 50 million Brazilians cannot afford medicines because of their low purchasing power: availability alone does not guarantee access and even with a correct diagnosis and prescription, the chances of therapeutic success are grossly minimized because of financial disempowerment (Santos, Nitrini, 2004). In Brazil therefore, before considering patient adherence to a specific medical treatment, their financial capacity needs to be evaluated and weighed up in order to establish whether access is guaranteed at all (Milk, Vasconcellos, 2003).

\section{The patient-healthcare professional relationship}

The services undertaken and performed by Romelândia pharmacy staff were, from a medico-socio perspective, identified as a strength. That the town merely boasts 5,551 inhabitants carries with it the advantage that healthcare professionals know their patients, often on a first name basis, as well as the families, living conditions, and social situation of each service user. Given this proximity to cases, the patient-health professional relationship is advantageous, facilitating communication and community trust, as seen by Milk and Vasconcellos (2003) in the coastal city of Itajaí, SC, Brazil: healthcare professionals using popular and less formalized communication demonstrated greater respect for patients and their cultural values. Additionally, patients had greater confidence in the health care professional who in turn saw fewer discriminatory attitudes.

That the majority of patients surveyed in our study $(66.6 \%)$ had a low level of formal education (corresponding to complete or incomplete elementary school) may go some way towards explaining why medication counseling and advice are not commonly perceived as weaknesses to service delivery. What's more, several patients expressed that the doctor was the first source of medical counsel, rather than the pharmacist. In the eyes of the service user, the pharmacist is a dispenser of prescribed medication rather than a health professional trained and qualified to advise on the use and course of pharmaceutical treatment.

More than half the professionals (57.1\%) interviewed in our study were educated to graduate level, with the others completing high school. When asked about their work and the positions held in the Municipal Health Secretariat, all interviewees stated that they worked in a specific, delegated area, except for the administrative clerk who also works as a pharmaceutical assistant and is the only worker working full-time in the pharmacy. Moreover, we observed that the municipal pharmacist (who works in the pharmacy) not only has responsibility for the routing process related to special medicines but also works in the town clinical laboratory. This means that most PA cycle duties are performed by an administrative clerk, a pharmaceutical assistant, and two nurse technicians, who also distribute medicines, administer vaccinations, apply bandages, and check blood pressure.

With regards to the role of medicines in public health, all professionals used positive wording such as "essential", "necessary", "fundamental", "extremely important", and even "means to a cure". Despite this, it was observed that PA concepts were neither clearly nor fully defined for the working realities of Romelândia healthcare professionals. Most of the time, PA was mistaken to be nothing more than "pharmaceutical care" or merely "prescribing and dispensing": professionals would often say that PA was exclusively "assisting in, and recommending, the use of medication" or "advising on proper use". In some cases, PA was even reduced to the distribution of "basic medicines freely provided by the public healthcare system". Evidently, service delivery is structurally weakened by the pharmacist's role being poorly defined in a health system which precisely requires the full participation of skilled healthcare professionals to meet the demands of a local population.

What's more, such answers regarding the role of medicines are simple where even for healthcare professionals, medication appears to be the panacea for public health problems, or as proposed by Lefebvre, "symbolic goods" (1991), where the only way to being healthy is through the consumption of medication (Leite et al., 2008). Indeed, in terms of pharmaceutical assistance, our study revealed that staff had a poor and somewhat under-developed understanding of the Ministry 
of Health's recommendations and guidelines: for the service professionals, pharmaceutical assistance begins and ends with prescribing and dispensing. Likewise in a similar study, Costa (2005) found that healthcare professionals, when referring to PA, focused solely on the supply and demand of medication; where the pharmacists themselves failed to identify concepts and phases crucial to pharmaceutical care and PA.

Pharmaceutical care and pharmaceutical assistance are distinct issues that should be clear in the minds of healthcare staff and to the working reality of the pharmacist who has the responsibility for proper, cohesive pharmaceutical care. PA, in turn, should be consciously implemented by all staff in a multi-professional way, soliciting pharmacist participation and engagement. The Pan American Health Organization (PAHO) (2002), in the Brazilian Consensus on Pharmaceutical Care, introduces a concept for such practice: Pharmaceutical care is a model of pharmacy practice, developed in the context of Pharmaceutical Assistance. It includes attitudes, ethical values, behaviors, skills, commitment and coresponsibility in disease prevention, health promotion and recovery in an integrated way. It is the patient-pharmacist interaction aimed at promoting rational pharmacotherapy and achieving defined and measurable results to improve life quality. This interaction must also respect the concepts of its subjects, considering their bio-psycho-social particularities according to the integrity of health services.

\section{Treatment adherence and availability of medicines}

The healthcare team believes that the lack of medicines is due not only to the scarcity of financial resources but to a series of incorrect priorities established and scheduled by both municipal managers and the procurement department. This was also identified as the main reason for the inappropriate purchasing of medication and reductions in essential drug listings issued by the town pharmacy. Managerial inconsistency is, according to the professionals interviewed, a continuous ongoing occurrence and is accepted as best practice (see Table II).

The health professionals interviewed in our study also identified general knowledge gaps in patient awareness given that service users failed to continue and follow through treatment. This situation can be likened to a double-edged sword for at the same time as professionals are not committed to or motivated by their role in health education, patients are not encouraged and counseled with regards to their prescribed treatment. The result is that both service user and health professional are de-valued within a
TABLE II - How health care professionals view the availability and use of medication

\begin{tabular}{lc}
\hline Viewpoint & $\%$ \\
\hline Non-availability of medicines at the pharmacy & 71.4 \\
\hline Non-adherence to treatment & 57.1 \\
\hline Inappropriate purchasing & 14.2 \\
\hline
\end{tabular}

complacent relationship which fails to meet the demands of service delivery.

Yet the failure to adhere to treatment is caused by certain weaknesses in healthcare services, as highlighted by the Journal of Primary Healthcare (Brazil, 2009): decisive factors of disease, treatment, patient disposition, and service delivery, including the complex language used by healthcare professionals (often alienating service users) are the most telling variables.

An interdisciplinary healthcare team therefore has the responsibility and professional capacity to encourage compliance through community engagement, that is, a working knowledge of individual, familiar, and social contexts making up the healthcare scenario of a given population. In this way, where cases present challenging cultural variables to service delivery, strategies can be created for effective communication and establishing affective bonds (Brazil, 2009). Enhancing user awareness during dispensing, pharmaceutical counseling, or pharmacotherapeutic monitoring are recommended strategies for promoting adherence to treatment but not forgetting that adherence is a multidimensional and unique phenomenon, at times difficult to broker, initiate, and maintain. To promote adherence, it is absolutely necessary to improve the patient-healthcare professional relationship by understanding the factors and (socio-economic/sociocultural/socio-pathological) variables which can lead to non-adherence. Similarly, recognizing and valuing popular knowledge can enable treatment continuity and cohesion, and empower patients to confidently assume the responsibility and management of their own care (Brazil, 2009). Responsibility therefore falls on the healthcare team and the patient alike: both must engage, assume an integral role in a process, and have a knowledge and perception of the variables, risks and benefits involved. In other words, all healthcare professionals must engage in the creation of viable strategies to promote treatment compliance, provide multidisciplinary services that meet legislative and public requirements, shared responsibilities and a public health vehicle with mutual understanding (Brazil, 2008). In this way, the roles of service user and healthcare professional can realize their necessary social and legislative value. 


\section{Activities of the healthcare professional}

Concerning the tasks performed by each professional and the delegation of responsibility, our study observed that the municipal doctor, although prescribing and instructing patients, ignored most stages of the PA cycle. The pharmacist, however, despite being contracted for only 20 hours per week in the pharmacy, was able to participate in several phases of drug management. The two on-site nurses dispensed medicines and instructed and advised patients whilst the administrative clerk (who performs all PA cycle steps except for prescription) and the nursing technician had the greatest responsibility and duty. Our findings indicate that although technical personnel are involved in the PA cycle, many steps are still not assigned to healthcare staff other than the pharmacist. Moreover, technical personnel are awaiting specific training for many stages in the PA cycle. All healthcare professionals must, and should participate in PA actions, with service coordination and monitoring falling to the pharmacist alone.

When the Family Health Support Service (NASF) was officially created, the pharmacist's duties were also specified. These are: the coordination and implementation of PA activities in Primary Care/Family Health; assisting health managers and the healthcare team in planning PA activities and services; promoting access to medicines and their rational use; ensuring proper dispensing; selecting, scheduling, distributing, and dispensing medicines in a safe and timely manner; properly receiving, storing, and distributing medications; and monitoring and assessing use, demand, and supply (Brazil, 2008).

Our study observed that during the initial drug selection stage, Romelândia was without a P\&T Committee and, most tellingly did not have a List of Essential Medicines (LEM). Even small towns need a committee because it $[. .$.$] is responsible for selecting and prioritizing$ medicines, whereas a LEM can be created to effectively meet the needs of a target population (Marin et al., 2003). A Committee is also responsible for the therapeutic format and other complementary activities promoting RUD and access to medication.

In Romelândia, the criteria used for drug selection are based on drugs which form part of the basic pharmacy list and on prescription demand without reference to clinical efficacy criteria or epidemiological profile of the population. According to the Brazilian Ministry of Health, drug selection must take into account epidemiological, economic, therapeutic factors, and the safety of medicines to avoid marketing and interpersonal pressures, this minimizes the existing model which is based on medical consultation.

The administrative clerk, assisted by the pharmacist, holds chief responsibility for the PA cycle scheduling phase. Crucial to this stage, is historical consumption data gathered from the inventory control system and centralized in the municipal pharmacy. This historical consumption method is the safest approach for estimating quantities. This method may fail where reliable data does not exist or there are lengthy drug shortages (Marin et al., 2003).

The limited availability of essential items in Romelândia may indicate that the scheduling stage is absent, inappropriate, or incipient. For Dupim (1999), it is the lack of proper strategic planning which leads to disproportionate availability, namely, a shortage of certain medicines and a surplus of others.

According to the professionals interviewed in our study, this stage would improve if respected by management and procurement. Yet the cost-reduction analyses undertaken by these local government departments drastically reduce projected medicine quantities. The result is that the purchasing phase of the PA cycle is blighted: without proper planning and cohesive projection, purchasing fails to meet demand leading to flagrant unavailability and compromised public health and outreach initiatives. Due to these cost-cutting measures and the social and professional problems caused by drug shortages, the purchase of medicines represents a serious weakness in the Romelândia PA cycle, if not an explicit threat to long-term public health equity and the wellbeing of its dependent population.

Most of the dispensing/delivery of medicines at the municipal pharmacy is performed by the administrative clerk, the nurse technician, or the nurses; only occasionally by the pharmacist. Such a routine is inconsistent with and contradictory to Pharmaceutical Practice guidelines (Resolution 2001) which stipulate the presence of a pharmacist during dispensing: "the presence and role of the pharmacist is crucial during the dispensing of patient medication; this is a non-delegable primary duty, and may not be performed by mandate or representation". (Arrais et al., 2009). Similarly, Veber et al. (2011) rightly identify the lack of pharmaceutical professionals engaged in PA services in almost half of the cities in Santa Catarina State. They found that improvements in care quality, management structure, user services are not viable without the participation of such professionals.

During dispensing, the pharmacist has unique opportunities to promote RUD. This can be achieved through the proper storage of high-end medication; observing the technical and legal validity of a prescription; advising the patient on correct usage; promoting adherence to the prescribed therapy; interacting with the patient by monitoring medication use and adverse event recording 
(Marin et al., 2003). Additionally, WHO suggests that the pharmaceutical dispensing process should take at least three minutes, as during this time important information can be transmitted, such as the emphasis on prescription compliance, food medicine interactions, and possible adverse reactions (Santos, Nitrini, 2004). Likewise, Kauffmann et al. (2009) asserted that "medication can be used rationally, and to ensure access, the patient must be educated about his/her drug therapy". Also stressed was the importance of shared responsibility in an inter-disciplinary process: "requiring the engagement of municipal managers, prescribers, professionals responsible for the drug dispensing process, and healthcare system users".

\section{FINAL CONSIDERATIONS}

PA activities in Romelândia require substantial structural improvement, if the demands of the community and the best practice protocols of the Ministry of Health are to be met. The drug selection phase must be based on the epidemiological profile of the population and the creation of a P\&T Committee and municipal LEM must be considered fundamental components for delivering an improved health service. The scheduling of medicines suffers from systematic reductions leading to low quantities, and the absence of a full-time qualified pharmacist means that patient counseling and trust building is drastically irresolute.

Over the course of this study, we observed that both technical and academic professionals substitute the pharmacist in certain stages of the PA cycle and in municipal drug management. The pharmacist, assisted by the entire healthcare team, is the professional responsible for selecting, scheduling, receiving, storing, distributing, and dispensing medicines, thus ensuring the quality and safety of the service. A full-time pharmacist within the pharmacy and in the Primary Healthcare Unit is crucial for more effective staff integration and a more cohesive service delivery.

The general, if not worryingly apparent lack of medicines is highlighted by both patients and healthcare professionals as a fundamental weakness in the service. Poor counseling protocols during medication dispensing are worsened by the absence of a full-time pharmacist in the municipal pharmacy. Owing to this pressured scenario RUD cannot be adequately promoted and both the service and its users remain part of a precarious routine which neither meets the structural needs of public health or the medical needs of the community.

We did, however, observe a high level of patient satisfaction in terms of attention received, this was enhanced by the staff's understanding of the problems and obstacles encountered by service users. Patient perception of the drug dispensing process, however, highlights a gross deficiency in pharmaceutical counseling with regard to possible interactions with foods, beverages, or other medications, as presented in Table I.

The apparent difficulty in understanding the correct use of medication and the consequent non-compliance with treatment occurs due to the patient's low service user awareness (public awareness). The responsibility of the pharmacist is to precisely inform and explain to patients the proper and rational use of medicines, and their adverse effects and possible interactions.

Finally, our study indicates that the PA cycle in Romelândia must be improved to achieve service delivery and quality control, principally for the selection, scheduling and dispensing stages. Additional improvements providing a more comprehensive communication protocol (counseling on the use of medication and the establishment of a pharmaceutical policy in the city) would mean that both the service and its public can work awareness: the service towards PA cycle actions, the public towards medication needs and therapy courses to improve quality of life.

\section{ACKNOWLEDGEMENTS}

The authors are grateful to the Ministry of Health (Brasilia) for their financial and technical support and to the Chapecó Regional Community University (Unochapecó) for facilitating research into Pharmaceutical Assistance Management.

This study forms part of the Capacitação de profissionais atuantes na assistência farmacêutica da Rede Pública (Training of Pharmacy Professionals working in Public Healthcare) project, co-sponsored by the Ministry of Health and Fundeste/Unochapecó, grant $n^{\circ} 1408 / 2008$.

\section{REFERENCES}

ARAÚJO, A.L.A.; PEREIRA, L.R.L; UETA, J.M.; FREITAS, O. Perfil da assistência farmacêutica na atenção primária do Sistema Único de Saúde. Ciênc. Saúde Coletiva, v.13, suppl., p.611-617, 2008.

ARRAIS, P.S.D.; BARRETO, M.L.; COELHO, H.L.L. Aspectos dos processos de prescrição e dispensação de medicamentos na percepção do paciente: estudo de base populacional em Fortaleza, Ceará, Brasil. Cad. Saúde Pública, v.23, n.4, p.927-937, 2007. 
BRASIL. Portaria n 3.916/GM, de 30 de outubro de 1998. Aprova a Política Nacional de Medicamentos. Diário Oficial da União, 1998. Avaiable at: <http://www.anvisa. gov.br/legis/consolidada/portaria_3916_98.pdf $>$ Accessed on: 26 Jan 2013.

BRASIL. Lei n ${ }^{\circ} 8.080$, de 19 de setembro de 1990. Dispõe sobre as condições para a promoção, proteção e recuperação da saúde, a organização e o funcionamento dos serviços correspondentes, e dá outras providências. Diário Oficial da União, Brasília, 20 set. 1990. Seção 1, p.18055.

BRASIL. Ministério da Saúde. Secretaria de Políticas de Saúde. Departamento de Atenção Básica. Gerência Técnica de Assistência Farmacêutica. Assistência farmacêutica na atenção básica: instruções técnicas para sua organização. 1.ed. Brasília: Ministério da Saúde; 2002. 116 p.

BRASIL. Conselho Nacional de Saúde. Resolução n 338 de 06 de maio de 2004. Aprova a Política Nacional de Assistência Farmacêutica. Diário Oficial da União, Brasília, 20 maio 2004. Seção 1, p.52.

BRASIL. Ministério da Saúde. Secretaria de Ciência, Tecnologia e Insumos Estratégicos. Departamento de Assistência Farmacêutica e Insumos Estratégicos. Assistência farmacêutica na atenção básica: instruções técnicas para sua organização. 2.ed. Brasília: Ministério da Saúde, 2006. 90 p.

BRASIL. Portaria GM n ${ }^{\circ} 154$ de 24 de janeiro de 2008. Cria os Núcleos de Apoio à Saúde da Família - NASF. Diário Oficial da União, Brasília, 24 jan 2008. Seção 1, p.39.

BRASIL. Ministério da Saúde. Secretaria de Atenção à Saúde. Cadernos de Atenção Básica: Diretrizes do NASF - Núcleo de Apoio à Saúde da Família. Cadernos de Atenção Básica, n.27. Brasília: Ministério da Saúde; 2009. 164 p.

COSTA, C.M.M. Assistência farmacêutica no programa saúde da família em Belém-Pará: organização, desafios e estratégias de reestruturação. Porto Alegre, 2005. 132 p. [Dissertation of master degree. Federal University of Rio Grande do Sul].

DUPIM, J.A.A. Assistência farmacêutica: um modelo de organização. Belo Horizonte: SEGRAC, 1999. 79 p.
GUERRA Jr, A.A.; ACÚRCIO, F.A.; GOMES, C.A.P; MIRALLES, M.; GIRARDI, S.N.; WERNECK, G.A.F.; CARVALHO, C.L. Disponibilidade de medicamentos essenciais em duas regiões de Minas Gerais, Brasil. Rev. Panam. Salud Publica, v.15, n.3, p.168-175, 2004.

IBDC. Instituto Brasileiro de Defesa do Consumidor. Faltam remédios essenciais no SUS. Consumidor SA, n.69, p.1419, 2003.

IBGE. Instituto Brasileiro de Geografia e Estatística. Censo Demográfico 2010: Primeiros dados: Santa Catarina. Rio de Janeiro; Avaiable at: http:/www.censo2010.ibge.gov.br/ primeiros_dados_divulgados/index.php?uf=42. Accessed on: 21 Nov. 2011.

KAUFFMANN, C.; FERNANDES, L.C.; DEITOS, A.; LASTE, G.; HEBERLÉ, G.; CASTRO, L.C.; TORRES, I.L.S. Analysis of pharmaceutical assistance in the Taquari Valley, Rio Grande do Sul: profile of service users and access to medication. Braz. J. Pharm. Sci., v.45, n.4, p.778-785, 2009.

LEITE, S.N.; VASCONCELLOS, M.P.C. Adesão à terapêutica medicamentosa: elementos para discussão de conceitos e pressupostos adotados na literatura. Ciênc. Saúde Coletiva, v.8, n.3, p.775-782, 2003.

LEITE, S.N.; VIEIRA, M.; VEBER, A.P. Estudos de utilização de medicamentos: uma síntese de artigos publicados no Brasil e América Latina. Ciênc. Saúde Coletiva, v.13, suppl., p.793-802, 2008.

LEFÉVRE, F. O medicamento como mercadoria simbólica. São Paulo: Cortez, 1991. 159 p.

MARIN, N.; LUIZA, V.L.; CASTRO, C.G.S.O.; SANTOS, S.M. (Orgs.) Assistência farmacêutica para gerentes municipais. Brasília: OPAS/OMS, 2003. 336 p.

OMS. Organización Mundial de la Salud. El papel del farmaceutico en el sistema de atención de salud. Informe de un grupo de consulta de la OMS. Nueva Delhi: OMS, $1988.41 \mathrm{p}$.

OPAS. Organização Panamericana de Saúde. Consenso Brasileiro de Atenção Farmacêutica: proposta. Brasília, 2002. 30 p. 
RESOLUÇÃO n 357 de 20 de abril de 2001. Aprova o regulamento técnico das Boas Práticas de Farmácia. Conselho Regional de Farmácia. Diário Oficial da União, Brasília, 27 abr 2001. Seção 1, p.24-31.

ROMELÂNDIA. Secretaria Municipal de Saúde. Plano Municipal de Saúde 2010-2013. Romelândia, SC, 2009. $28 \mathrm{p}$.

SANTOS, V.N.; NITRINI, S.M.O.O. Indicadores do uso de medicamentos prescritos e de assistência ao paciente de serviços de saúde. Rev. Saúde Pública, v.38, n.6, p.819834, 2004.
SILVA, T.; SCHENKEL, E.P.; MENGUE, S.S. Nível de informação a respeito de medicamentos prescritos a pacientes ambulatoriais de hospital universitário. Cad. Saúde Pública, v.16, n.2, p.449-455, 2000.

VEBER, A.P.; DIEHL, E.; LEITE, S.N.; PROSPERO, E.N.S. Pharmaceutical assistance in local public health services in Santa Catarina (Brazil): characteristics of its organization. Braz. J. Pharm. Sci., v.47, n.1, p.75-81, 2011.

Received for publication on $20^{\text {th }}$ August 2012 Accepted for publication on $30^{\text {th }}$ September 2013 
